\title{
Building the economic-public relationship: learning from science communication and science studies.
}

\section{Fabien Medvecky and Vicki Macknight}

\begin{abstract}
There is a gap between the discipline of economics and the public it is supposedly about and for. This gap is reminiscent of the divide that led to movements for the public understanding of and public engagement with the natural sciences. It is a gap in knowledge, trust, and opinions, but most of all it is a gap in engagement. In this paper we ask: What do we need to think about - and what do we need to do - in order to bring economics and its public into closer dialogue? At stake is engaged, critical democracy. We turn to the fields of public understanding of science and science studies for our approach, finding three themes of particular relevance: understanding, expertise, and audience. We then discuss participatory budgeting (PB) as an example of fertile ground for engagement. We argue that with an economic-engagement focus, activities such as PB could be extended into the public-economics gap and provide avenues for an economic equivalent of participatory science: a form of participatory economics.
\end{abstract}

Keywords

Participation and science governance, Public engagement with science and technology, Public understanding of science and technology

The public, it seems, does not know much about economics [Walstad, 1997; Walstad and Rebeck, 2002; Blinder and Krueger, 2004; Jappelli, 2010], nor does it share the opinions of economists [Sapienza and Zingales, 2013; Johnston and Ballard, n.a.]. They do not trust economics to be able to contribute much to solving social challenges, even those challenges economists would see as clearly within their remit, such as natural resource management [Medvecky and Macknight, 2015]. Economists, for their part, seldom reach out to the public, instead inhabiting a notably insular disciplinary niche [Fourcade, Ollion and Algan, 2015], and they have little expectation that anyone will read their work beyond colleagues and graduate students [Davis, 1997; Davis, 2007]. Yet economics affects (and often dictates) large swaths of our decisions, both social and personal. What do we need to think about - and what do we need to do - in order to bring economics and its public into closer dialogue?

Economics is a messy term, and before proceeding, we want to anchor down what we mean before out language leads us astray. In this paper, we use the term 'economics' to refer to the discipline of economics, including its research, methods, findings and applications. We differentiate "between economics and economy, 
between theoretical and practical activity, in short, between economics as a discipline and economy as a thing" [Callon, 1998]. Economics as a discipline is a social science - one primarily concerned with the study of decision making in the face of scarce resources - and many of the observation we make in this paper could be applied to other social sciences. However, economics is unique in the social sciences for its insularity and for being the least likely social science discipline to value interaction with other disciplines. As Fourcade, Ollion and Algan [2015] note, "Economists are the only ones in this group among whom a (substantial) majority disagree or strongly disagree with the proposition that in general, interdisciplinary knowledge is better than knowledge obtained from a single discipline' " [p. 95]. This makes the interaction between economics (as a discipline) and its various publics uniquely interesting. Yet these are issues that have been little studied, especially compared to the effort expended on the public's relationship with the natural sciences.

The public interaction with natural sciences has been the subject of extensive research since the 1980s, with the recognition, among others, that knowing about science is important for private and collective decision making. A society where people know more about the scientific issues at stake is arguably a better society because the public would be able to make better personal, business, and democratic decisions [Thomas and Durant, 1987]. Following the same logic, we should likewise work to build dialogue between the social sciences and its public, including between economics and its publics; knowing more about economics would help people make better personal, business, and democratic decisions, or at least it would allow the public to enter into critical dialogue around economic issues.

We will discuss the public-economics gap with reference to work done in Public Understanding of Science (PUS) and Science Studies (also referred to as Science and Technology Studies or STS). From those fields we borrow some key questions around understanding, expertise, audience, democracy and politics, and ask these same questions with regard to economics. We close with a discussion of Participatory Budgeting (PB), a set of hugely successful programs worldwide that aim, at least in theory, to democratize and open up the black box of public-policy making. We argue that these programs might be extended to bridge the gap between economics and its publics and become a fertile ground for engagement with economics by bringing the economics of public-policy making more sharply into focus during the PB process.

The economics-public gap

\begin{abstract}
'[T]he very real success of economists in establishing their professional dominion also inevitably throws them into the rough and tumble of democratic politics and into a hazardous intimacy with economic, political, and administrative power. It takes a lot of self-confidence to put forward decisive expert claims in that context. That confidence is perhaps the greatest achievement of the economics profession - but it is also its most vulnerable trait, its Achilles' heel.' [Fourcade, Ollion and Algan, 2015, p. 111]
\end{abstract}

According to Fourcade and colleagues, the prominence of economics has been built into the culture of the discipline, at least as it has evolved in the United States, through practices that keep economics insular from other disciplines; strongly 
hierarchical within its own; and happily linked to the strong and prosperous schools of finance and business which command high levels of material wealth as compared to almost all other academic disciplines (as well as most other people) [Fourcade, 2009]. This results in a 'growing social distance of economists from the public at large [which] would be irrelevant if economists were not making it their mission to maximize the welfare of ordinary people' [Fourcade, Ollion and Algan, 2015, p. 107]. This distance between economists and its publics is also acknowledged by economists. In two surveys, William Davis found that economists strongly agree that economists are ineffective at communicating with the public and that publications in economics journals are of very little use to anyone, apart from professional economists and graduate students [Davis, 1997; Davis, 2007; See also Blendon et al., 1997; Jacob, Christandl and Fetchenhauer, 2011; Kemp, 2008] While many features of the economy are reported in the media - such as GDP growth, employment figures, and changes to interest rates - there is less discussion of what these figures mean and how they are arrived at. In reporting news about the economy, economic knowledge is assumed.

Being at such a distance from other disciplines and from the public might be a comfortable position for many economists, but it is concerning if we take seriously the role of economists in shaping government and public policy. And it certainly should be a concern when we remember economics' origins as a determinedly moral, socially inflected philosophy. After all, Adam Smith, the 'father' of economics, was first and foremost a moral philosopher. More troubling, there is also a major lack of public confidence in economics. Indeed, a recent survey show that the American public have little confidence in economics even to solve the types of problems that are generally assumed, at least by economists, to be part of economics' core domain [Medvecky and Macknight, 2015]. These include dealing with climate change, environmental protection, and natural resource management.

A social studies of economics?
Surprisingly little work has been done to understand the relationship between the discipline of economics and the public. As Johnston and Ballard state, 'Given their increasing presence in the public sphere, what role do economic experts play in shaping public opinion on economic issues? Despite its growing importance, almost no research exists on this question' [Johnston and Ballard, n.a. p. 2] This research gap is particularly striking if compared to the scrutiny given to the relationship between science and its publics. There are well-established disciplines of science communication and STS carried out in university departments and specialty journals around the world. One particular line of inquiry these latter disciplines have focused on is public acceptance of and trust in science, at least initially with the explicit goal of increasing public trust [Bauer, Allum and Miller, 2007; Royal Society, 1985; Thomas and Durant, 1987]. It is this work (though not necessarily with same the implicit goal) we want to draw the attention of economists to: work that shows a sophisticated understanding of the complex relationships between knowledge, trust, and expertise, and that has important insights into ways to engage multiple publics in debates around ethics, values and futures [Gauchat, 2011; Sturgis and Allum, 2004; O'Brien, 2013; Barben, 2010]. While in the case of science engagement efforts there was a (now widely regarded as fallacious) assumption that knowledge leads to affection, we don't assume that an increase in economic understanding will lead to agreement with economist's 
conclusions. We simply hope that increased understanding of economics will enable more engaged and critical discussion between publics and economists.

\section{Three key} questions asked about science that need to be asked about economics
We have seen above that the majority of the American public sees economics as distant from them and as not important for solving what are likely to be big collective challenges in the coming decades. This is concerning given the dominant role of economics in policy making.

In stating the problem this way we intend to draw attention to questions of knowledge, power, and public confidence in economics as a discipline. In the discussion that follows, we highlight some reasons why these are important and difficult questions for economics, and suggest some factors that may be causing economics to lose public confidence; factors that should be better understood. We take our lead from social studies of science and science communication by considering three thematic questions.

\section{What is understanding?}

There has been a long intellectual struggle in the Public Understanding of Science movement to rid the discipline of the assumption that the public is ignorant of science. The positioning of the public as deficient in scientific knowledge was established in the 1970s through surveys that asked respondents to answer fact-based questions. When the public answer incorrectly, it was seen as proof that they needed to be taught more science. And who better to do that than expert scientists? [Miller, 2001, p. 116]

This cemented a divide between expert (scientists) and lay (publics). Over the following years, scholars noticed the analytic divide they had made and began to problemitise it. Were the public really so deficient in knowledge? What would happen if instead of thinking of scientific knowledge as recall of facts we thought about whether people could use scientific concepts in their everyday lives [Priest, 2013]? What would happen if we talked with non-scientists about a scientific topic that directly concerned their locally embedded lives [Wynne, 1998]? The ensuing shift in what counts as understanding and knowledge with regard to science has led to (at least in theory) a much more democratic approach to the relationship between science and the public [Bauer, Allum and Miller, 2007].

Economics needs to ask a similar set of questions. There have been plenty of surveys done to establish the publics' general ignorance of economics [Walstad and Rebeck, 2002; Blinder and Krueger, 2004; Markow and Bagnashchi, 2005]. This work has been used to add impetus to calls for wider economic education in schools and elsewhere [MacDowell, 1986]. Critiques of this work have been mainly based on the question of what it really means to know about economics [Salemi, 2005; Nelson and Sheffrin, 1991; Fettig, 1999]. Similar discussions around what should count as good knowledge have taken place around natural and other social sciences also. Should we be testing whether people can define economic terms, use economic concepts, do economic equations, or something else? Depending on how we measure, the public might appear less deficient in economic knowledge (see, for example, Williamson and Wearing [1996] who use qualitative open-ended 
questions, or Wobker et al. [2014] who try to establish minimum levels of economic knowledge for people to make sound decisions). Surveys have begun more recently to try to assess how competent people are at making financial decisions, especially around retirement savings [Lusardi and Mitchell, 2011; Lusardi and Mitchell, 2013]. But still, (and at least partly due to the continuing focus on literacy with economic language) the picture that emerges is of a public worryingly deficient in economic knowledge.

But what if, instead of starting with a presumption of ignorance, we asked people what they do know about economics? And what they care about and use in their locally embedded lives? The public may not know about the technical instruments economists use to measure, theorise, and impact the economy. But they do know something of what they want economics to do for them, their families, their communities and their environment. If economics is performative in the sense that Callon, Mackenzie and others claim - that is a discipline that changes the economy, rather than simply describing its state - then ordinary people perform the economy too [Callon, 2007; Mackenzie, 2006; Mackenzie, 2008; Holmes, 2009; Holmes, 2013]. Perhaps ordinary people, and economists too, could perform economics better and more effectively if they had more dialogue, and in particular if a key aim was the development of a shared language. If economics is to be a responsive and responsible social science these are things we need to know.

\section{How do expertise and democracy relate?}

Expertise has an awkward relationship with democracy. The question of expertise - and how much right we ought to confer upon experts - has been an active research question in science studies for some time. It is a difficult question for analytic reasons as well as more practical ones. There are tricky boundary making issues - who is an expert? Where does their knowledge come from? How much legitimacy does expertise give in deciding issues that extend into the public (social, environmental, legal, political, economic, etc) sphere?

There is a recognized tension shared by all sciences here, economics included - the necessity of experts in a complex modern economy versus the necessity of taking account of 'lay' public knowledge and desire. This tension is about how to simultaneously value technical expertise, experiential expertise and lay opinion. There is also the challenge of how to recognise and dissolve boundaries between multiple competing knowledges, desires and opinions so that discussion around economics can actually occur.

One way this debate has been approached in social studies of science is to argue that you can tell from a layperson because experts are able to contribute meaningfully to the discipline in question [Collins and Evans, 2002]. But crucially, experts should have no more right to decide on technical issues outside of their specific area of expertise than does any one else. Collins and Evans' aim is to firm up boundaries to help us assess whose knowledge is valuable when making decisions. Another way expertise has been approached is to think about how the divisions between experts and others have been made. The aim here is to facilitate discussion around scientific issues, including economic issues, and work out how barriers between people and their knowledge have been made so that they can be 
dissolved where appropriate [Jasanoff, 2003a; Jasanoff, 2003b; see also Irwin, 2001; Stirling, 2008; Branco, 2012; Engelen et al., 2012].

What we have learnt from science studies leads us to believe that two things need to happen around economics. The first is that we need to find ways that value other types of economic expertise. We need to look for the economic equivalent of Wynne's Cumbrian sheep farmers [Wynne, 1998]; people without economics qualifications, but who have locally embedded experience with economics meaningful to economic decision-making. The second thing that needs to happen is for more spaces to be opened up for a public discussion of economics. These spaces would be sites for actively decoupling expert knowledge from the right to make decisions. We will consider some possible sites a little later.

\section{Who is and who should be considered 'the public' or 'the audience'?}

Publics and public/expert spaces have been a topic of science studies for some time. One place this has been made particularly obvious has been in so-called 'citizen science' - science where the public participate, such as lay people volunteering to collect data. Citizen science does not attract all of the public, however. The people who choose to become involved are generally educated, middle-class and white [Edwards, 2014].

Gauchat [2011] points out that there are social, economic and cultural rewards that make it desirable for some people to know about and to engage in science, and others not to. The trouble for democracy is that if knowing about and engaging with science maps onto already existing patterns of privilege, then the ability to contribute to discussions and decision making around science falls unevenly. 'Here the question becomes: do meaningful groups emerge based on dispositions toward science, are these groups socially unequal, and do they correspond to political divisions and distinct life-styles?' [p. 767] This is an issue for economics also. It is clear from surveys that some demographics in the United States know more about economics than others. It might come as little surprise to find that those who tend to know the most are white, financially comfortable, middle-aged, and male [Blinder and Krueger, 2004; Walstad and Rebeck, 2002; Lusardi and Mitchell, 2011].

The problem of the public does not dissolve when we rename them publics because multiple publics can map so neatly onto other patterns of inequality. This is not to say that ignorance of economics causes inequality, nor necessarily the other way around. But it does indicate something of the way power to speak on economics is unevenly socially distributed. Much more could be done to better understand who knows what about economics, and how this knowledge is socially distributed. Resources have been put in place to enhance people's, especially economically marginalised people's, ability to use financial instruments like budgets, interest rates, and stock markets [Lusardi and Mitchell, 2013, http:/ / www.oecd.org/ finance/financial-education/]. However, much of these resources are simply placed on the internet, waiting for interested parties to find them (www.mymoney.gov/; https://www.sorted.org.nz/). Importantly, the ability to use instruments relevant for personal finance, while valuable, stops far short of building broader economic capacity or understanding. It also puts the onus of managing finances on individuals, short-circuiting the need for governments to better regulate the economy [Willis, 2008; Poon and Olen, 2015]. 
Only once we better understand who knows what about economics - and what they want and need to know - can we start to develop better tools to engage (and not simply broadcast to) diverse publics, audiences and stakeholders with economics. If we can begin to give (more and marginalised) people the tools to better understand and operate with economic concepts, we also empower them to join in what should be a public discussion about how value collective resources. Or perhaps the process should go the other way: empower people to make decisions and then develop the tools they need to understand economics.

\section{What can Participatory Budgeting do for the public-economics relationship?}

Given that the public(s) have little knowledge of economics, little agreement with economists, and little faith that economics can solve major public problems, we want to suggest a possible site for public engagement with economics: Participatory Budgeting (PB). We will revisit the themes discussed above (understanding/knowledge building; expertise and democracy; and audiences and participants), and for each of these, we will show how the practices of PB contain both possibilities and limitations. While PB is in some ways as wonderful as proponents say [Cabannes, 2004; Souza, 2001], it does have some clear limits evident when we look through an economic lens. While PB could be and should be considered as a site for engagement with economics, discussions so far have largely focused around political questions of democracy. In contrast to citizen science, where the complex relationship between science and democracy have been explored [Irwin, 1995; Jasanoff, 2011; Kinchy, 2017], PB has been assumed to be solely about democracy, and not about economics. We will argue that thinking about PB through an economic lens helps us to see how PB could be expanded to bring the public into discussions around economics.

We have chosen to focus on PB for several reasons. One is that it exists as one of the only sites where the public is invited to contribute to states' economic decision making. More, it has been widely studied, and hence has enough scholarly legitimacy that economists and others should recognise it. This means it is easy to imagine economists using PB forums to guide research questions in ways reminiscent of Responsible Research and Innovation [E.C., 2013; Owen, Macnaghten and Stilgoe, 2012]. It is a site that invites publics to contest value in their socio-polity, and in doing so have potential to perform economics and the economy in new ways.

\section{What is Participatory Budgeting?}

$\mathrm{PB}$ is the general term for a very wide range of programs run in 1,500 cities internationally in which citizens are given a say over how a portion of public money is spent. The first and most famous instance of PB was developed in Port Alegre, Brazil. This came about in 1989 when the newly elected Workers Party found itself working-out, in an ad hoc manner, how citizens could participate in making decisions around spending some city revenue. The intent was to allow economically marginalised people a say in public spending in order to re-distribute some public resources [Marquetti, Silva and Campbell, 2012, p. 62-63]. To see how PB processes can work in practice, let's look at the Californian city of Vallejo's 2012 PB project. The process had four main stages. First, community meetings were held with interested residents, stakeholders, and staff from the city council, including PB 
staff. Ideas were shared, and budget delegates volunteered. Proposals were developed by budget delegates and experts in the next stage, ready to be submitted to the city and steering committee for approval. Residents were invited to vote on proposals, and the most popular were again submitted to the city for consideration. Finally, the participants evaluated the process, and projects were implemented. In 2012, twelve projects were approved, including fixing potholes, improving lighting and parks, installing public safety cameras, and supporting community gardens (http://www.ci.vallejo.ca.us/city_hall/departments__divisions/city_manager/ participatory_budgeting/, accessed 14 March 2016). Most PB projects work at the city level, but it has been used at other levels of government too.

PB is very different from the similarly named Participatory Economics or Democratic Economics, which are theoretical programmes that re-think the entire economic system to give more rights and power to the public and aim to 'democratize workplaces, finance, investment, and the market system' [Malleson, 2013, p. 84; see also the brilliant Malleson, 2014]. We focus on PB as a site for engagement with the discipline of economics because PB has been enacted all over the world, while the Participatory Economics and Democratic Economics are primarily politically embedded theoretical programmes with only a little piecemeal enactment. These others could also be fruitful sites of public-economic engagement, but are harder to find in practice. What we want to consider here is the possibilities to expand $\mathrm{PB}$ as a site for public engagement with economics as a discipline; with economics as a research field and a body of knowledge. We will explore this in terms of the three themes discussed above: understanding, expertise and publics.

\section{1. $P B$ and public understanding of economics}

As we saw in the case of science, expertise has a tense and difficult relationship with democratic decision making. This is true, too, in PB. PB projects enhance understandings of local economic conditions. These are about the economy: the actually existing relationships between people, money, production and trade. Discussion and decisions focus on how to change these relationships somewhat. For example, in a cash strapped municipality, discussion might focus around how to better share tax burdens and ways to increase tax revenue [Wampler, 2000, p. 7]. But all these values, and the decisions reached, are about what people want money to do for them, not more generally about what they want economics to value either in economic policy or economic concepts. An example will make this clearer. Imagine a PB discussion about funding a community garden. Discussion is likely to first centre on how it might change conditions in the economy (reduced food prices, productive work, etc). If the conversation is broadened though it can also include economic concepts (what is valued as a resource, scarcity, supply/demand and prices of fresh food, opportunity costs if time in spent gardening, etc). For such discussions to occur the focus needs to be expanded from being a process about democratizing decisions to one that specifically democratizes economic discussion, where the economics is made explicit. This could be as simple as naming concepts at appropriate moments.

It could be said that what participants are likely to gain from the varied projects is community-based financial literacy, as opposed to economic literacy. While the financial literacy they do gain is highly valuable and goes well beyond the 
individually focused picture of financial literacy presented by Lusardi and others [Lusardi and Mitchell, 2008; Lusardi and Mitchell, 2009; Lusardi, 2015; for a critique see Poon and Olen, 2015], it does not take the next step into economic literacy. Economic literacy overlaps with financial literacy but is broader [Engelbrecht, 2008], including resources other than money, such as time, skills and knowledge, social networks and so on. It would also include an understanding of economics as a system of thought, a logic made up of concepts [Stigler, 1970; Salemi, 2005].

One challenge to $\mathrm{PB}^{\prime}$ 's capacity as a site of engagement to enhance public understanding of economics is that the complexity of the language and process of politics that participants must learn is too demanding for most participants. Many people leave projects, and of those who stay, few become truly fluent. These few become 'expert citizens', with an expertise that they can use in other political institutions, reminiscent of AIDS activists who became expert in medical engagement [Epstein, 1995] or those citizens who have become experts in epidemiology [Brown, 1997]. The ability to take this step is not possible for many however, as Talpin points out; 'empowerment requires time and emotional commitment' [Talpin, 2012, p. 192]. The concern is that adding economics to the already complex set of knowledges participants are seeking might make participation in PB even more demanding.

\section{2. $P B$, expertise and democracy}

Describing the development of PB in Porto Alegre, one facilitator said, "As much as possible, technical expertise was to be made subservient to the popular mandate, and not the other way around" [Ganuza and Baiocchi, 2012, p. 5]. However, it would be a mistake to underestimate the importance of expertise in the Port Alegre case. Technical expertise was, in fact, essential to the smooth running of PB projects. Navarro explains that "[a]bove all, the [municipal] staff must have a thorough command of budget techniques" [2004, p. 205]. In PB processes, expertise is involved at several points and is treated as vital background information, a starting point for decision-making. For example, in Porto Alegre, reports are presented at the beginning of consultative stages. "The municipality every year must coordinate information about three years of $\mathrm{PB}$, an undertaking that requires significant staff resources and technical expertise [...] The COP [elected Council of the Participatory Budget] and the Planning Cabinet [part of the government] consider regions' priorities, the availability of financial resources and, when necessary, technical opinions. Municipal agencies then provide appropriate data and technical studies' [Navarro, 2004, p. 188]. What this shows is that even in the Porto Alegre case where expertise was meant to be subservient, technical expertise folds limits over the process. Technical financial limits are the building blocks of PB: after all, accounting instruments are necessary to calculate the amount of money available to PB projects (which will in turn depend on local and global conditions in the economy).

Expertise will likely always be a tension in PB projects because they are located within the technocratic world of political administration. While the pool of money set aside for PB projects can be as high as $20 \%$ of public revenue, that still leaves $80 \%$ (and usually much more) of public revenue in the hands of the technocratic bureaucrats and elected officials. Spending this larger sum of money is an expert 
decision. In some mature PB programs, there are 'thematic' as well as 'local' spending discussions, such as around transport or healthcare. However, these too face challenges of participant expertise. 'Broad policy decisions may be largely acts of rubberstamping as the majority of participants follow the lead of the most experienced policy advocates or the positions of the government' [Wampler, 2000, p. 16].

One serious tension over expertise and democracy in PB is that, as discussed above, to negotiate such spaces requires a level of expertise that not all participants will have. Moreover, as PB projects spread, experts in PB are produced; they know how PB can (should) be structured and how to run the process. This obviously can have very positive impacts. As Tyson Vaughan shows, in his discussion of participatory recovery planning in earthquake prone Japan, we should recognize the work 'engagement experts' as part of our understanding of the situated, on-going productions of technical and public expertise [Vaughan, 2014]. But it can also have the negative potential of creating inertia. As de Sousa Santos puts it, "a destabilizing idea that succeeds in becoming a sustainable practice is always in danger of losing its destabilizing potential as its success increases. The routine of mobilization leads to routine mobilization" [de Sousa Santos, 2005, p. 28]. In other words, PB experts hamper the ability for PB to be flexible and responsive to local circumstance, and instead the outcomes risks becoming "technically over-determined" [Ganuza and Baiocchi, 2012, p. 1]. There is danger not only in technocratic experts, but in PB experts too.

The challenge, we believe, is in recognising and valuing a range of different types of expertise. One is the expertise about the economy, held by local officials. This structures and limits possibilities before PB even starts. The second is experts in PB processes. While they are vital for the smooth functioning of PB processes, they may also tend to close down broad-ranging discussion and $\mathrm{PB}$ experts are not necessarily experts in economics. Finally, experts in facilitating and opening discussion should be fostered, particularly in their ability to name economic concepts and encourage discussion around economic possibilities. One very important task they would be charged with is developing participants' abilities to speak with legitimacy and authority to economic decision makers. Participants have already, and can further develop experiential expertise (like Cumbrian sheep farmers), but they need also to be able to contribute to economics (as Collins and Evans stress).

\section{PB, audiences and publics}

Because the academic focus has been placed on the democratic potentials of PB, much has been written about its inclusiveness. When thinking about who the audience is for PB - and who it could be and who it should be - we notice that in $\mathrm{PB}$ the collecting concept is geographical. Participants share a concern with a place and the people who live there. Concern is grounded on a park, or a street, or local rubbish and recycling. In fact, this can lead people to associate PB projects only with the specific place, and once the place has been improved, they leave PB [Wampler, 2000, p. 23]. Geographical proximity is, however, not the only way people can share concerns. People can gather around objects of shared interest even if they are geographically dispersed [Marres, 2005; Latour, 2005]. These shared 
issues may be about topics such as climate or pollution (and their objects like fish and icecaps), they may be about wider themes such as questions of equity and equality (and their objects like schools, books, menstrual products, and hospitals), or they may be about specific resources such as food (and their objects like wages, soil and free-trade certification). There are possibilities for Electronic-PB to sidestep geographic limits, though because PB budgets usually come from geographically defined areas, this possibility has so far not been realized [Nitzsche, Pistoia and Elsäßer, 2012].

Many of the barriers to participation in PB are not about access to democratic participation. They are instead about socio-economic structures. They are about who has time (and who is working, in or out of the home), they are about who has energy (and who works too hard to have any spare), they are about who can travel. McNulty [2015], for example, shows that Peruvian women find it difficult in practice to become involved in PB because the bulk of the domestic work falls upon them. Ideology of the ruling government may be the most important factor in determining participation of the economically marginalized. According to Bräutigam [2004], economically marginalized people are much more likely to participate if there is a pro-poor government in power. However, she suggests that the sector that really needs to participate more in PB is the business sector: "Experiences in some countries suggest that a sustainable pro-poor economic strategy might require the inclusion of the business sector as a partner in participation - and in providing the revenues necessary for the pro-poor spending" [p. 654]. Bringing in more business people, and therefore the revenue side, might also help support broader economic literacy among participants.

There are two directions we could think about for enhancing particaption. One is to make the various absences a topic for discussion within PB can further understanding of both the economy and economics. Noticing who is absent and why is a matter of the economy: the actual relationships people have with various kinds of work. Explaining the structures that have brought this about, what we lose when we lose those participants, and what we want instead are matters of economics: how we measure, value, conceptualise, and plan. The second way we could think takes us beyond geographical defined political bodies. A more productive way to think, however, would be around 'issues that spark a public into being' [Marres, 2005]. Issues such as climate change, pollution, natural resources, access to healthcare, all are local and global simultaneously and all have a clear economic component. The question we should ask then is not about who is not involved, but about how to draw together a shared interest, and such a drawing together can provide a rich site for public engagement with economics.

In this paper we have discussed the distance between economics and the general public and shown how such a distance is manifested in various ways and from both sides, including by economists publishing only for each other and the public not believing economics to be 'key' in solving big societal problems. We argue that this severely impacts the possibility of economics becoming a genuinely socially responsive discipline. In the 1980s, an equivalent distance was noticed between science and the public and practical steps were taken to reduce that distance, alongside academic attempts to study and understand it. This work is on-going and we have borrowed three lines of inquiry from the Public Understanding of 
Science, Science Communication and STS programmes that we believe ought to be asked of the economics-public gap also. These are: what is meant by 'understanding' when talking about a public understanding of economics? How do expertise and democracy relate with regard to economics? And, who is and who should be the audience for economics?

To locate our answers in a more practical setting, we used participatory budgeting as a case study of a widespread and practical program in which people make public decisions about economic matters. PB is a site that offers the chance to gather information about what people value, and what they want economic theories to do for them. We asked how far PB might reach into the gap between public and economics, and how it could be extended in order to reach further.

We have two key conclusions. One is that the types of questions asked, the answers given, and conceptual tools developed in science studies can be called into many other areas, and this is potentially very powerful - after all, science is not the only thing people should know about in order to make good personal and collective decisions. Thinking in this way shows that ideas about expertise, what it means to have good knowledge, who is able to speak with legitimacy and why, and how we can carry out more Responsible Research and Innovation in science and beyond are all highly relevant not only to science, but also to economics and beyond.

The second conclusion is that participatory budgeting has the potential to become a process that not only enacts democracy, but also opens people up to thinking about and engaging with economics. PB is already a powerful process to empower citizens to make changes in their local economy. But it could be more. Though there are undoubtedly challenges, $\mathrm{PB}$ could be expanded to develop citizens understanding of economic words and concepts, to gain legitimate expertise to speak on economics, and to understand why their economy is structured as it is and how it might be structured differently.

Barben, D. (2010). 'Analyzing acceptance politics: Towards an epistemological shift in the public understanding of science and technology'. Public Understanding of Science 19 (3), pp. 274-292. DOI: 10.1177/0963662509335459.

Bauer, M. W., Allum, N. and Miller, S. (2007). 'What can we learn from 25 years of PUS survey research? Liberating and expanding the agenda'. Public Understanding of Science 16 (1), pp. 79-95. DOI: 10.1177/0963662506071287. Blendon, R. J., Benson, J. M., Brodie, M., Morin, R., Altman, D. E., Gitterman, D., Brossard, M. and James, M. (1997). 'Bridging the Gap Between the Public's and Economists' Views of the Economy'. Journal of Economic Perspectives 11 (3), pp. 105-118. DOI: 10.1257/jep.11.3.105.

Blinder, A. S. and Krueger, A. B. (2004). 'What Does the Public Know about Economic Policy, and How Does It Know It?' Brookings Papers on Economic Activity 1, pp. 327-387.

Branco, M. C. (2012). 'Economics Against Democracy'. Review of Radical Political Economics 44 (1), pp. 23-39. DOI: 10.1177/0486613411418051. 
Bräutigam, D. (2004). 'The People's Budget? Politics, Participation and Pro-poor Policy: The People's Budget? Politics, Participation and Pro-poor Policy'. Development Policy Review 22 (6), pp. 653-668. DOI: $10.1111 / j .1467-7679.2004 .00270 . x$.

Brown, P. (1997). ‘Popular Epidemiology Revisited'. Current Sociology 45 (3), pp. 137-156. DOI: 10.1177/001139297045003008.

Cabannes, Y. (2004). 'Participatory budgeting: a significant contribution to participatory democracy'. Environment and Urbanization 16 (1), pp. 27-46. DOI: $10.1177 / 095624780401600104$.

Callon, M. (1998). 'Introduction: The Embeddedness of Economic Markets in Economics'. The Sociological Review 46 (1), pp. 1-57. DOI: $10.1111 / j .1467-954 X .1998 . t b 03468 . x$.

- (2007). 'What does it mean to say that economics is performative'. In: Do Economists Make Markets? On the Performativity of Economics. Ed. by F. M. D. MacKenzie and L. Siu. Princeton, N.J., U.S.A.: Princeton University Press, pp. 311-357.

Collins, H. M. and Evans, R. (2002). 'The Third Wave of Science Studies. Studies of Expertise and Experience'. Social Studies of Science 32 (2), pp. 235-296. DOI: $10.1177 / 0306312702032002003$.

Davis, W. L. (1997). 'Economists' Perceptions of Their Own Research'. American Journal of Economics and Sociology 56 (2), pp. 159-172.

- (2007). 'Economists' Opinions of Economists' Work'. American Journal of Economics and Sociology 66 (2), pp. 267-288.

de Sousa Santos, B. (2005). 'Two democracies, two legalities: Participatory Budgeting in Porto Alegre, Brazil'. In: Law and Globalization from Below: Towards a Cosmopolitan Legality. Ed. by d. Boaventura and C. A. Rodríguez-Garavito. Cambridge, U.K.: Cambridge University Press.

Edwards, R. (2014). 'The 'Citizens' in Citizen Science Projects: Educational and Conceptual Issues'. International Journal of Science Education, Part B 4 (4), pp. 376-391. DOI: 10.1080/21548455.2014.953228.

Engelbrecht, L. (2008). 'Economic literacy and the war on poverty: a social work challenge?' International Journal of Social Welfare 17 (2), pp. 166-173. DOI: $10.1111 / j .1468-2397.2007 .00544 . x$.

Engelen, E., Ertürk, I., Froud, J., Johal, S., Leaver, A., Moran, M. and Williams, K. (2012). 'Misrule of experts? The financial crisis as elite debacle'. Economy and Society 41 (3), pp. 360-382. DOI: 10.1080/03085147.2012.661634.

Epstein, S. (1995). 'The Construction of Lay Expertise: AIDS Activism and the Forging of Credibility in the Reform of Clinical Trials'. Science, Technology $\mathcal{E}$ Human Values 20 (4), pp. 408-437. DOI: 10.1177/016224399502000402.

European Commission (E.C.) (2013). Options for Strengthening Responsible Research and Innovation. Brussels, Belgium: European Commission.

Fettig, D. (1999). 'Seeking a blueprint for economic literacy'. The Region. The Region $13(2)$, pp. 3-7.

Fourcade, M. (2009). Economists and societies: Discipline and profession in the United States, Britain, and France, 1890s to 1990s. Princeton, N.J., U.S.A.: Princeton University Press.

Fourcade, M., Ollion, E. and Algan, Y. (2015). 'The Superiority of Economists'. Journal of Economic Perspectives 29 (1), pp. 89-114. DOI: 10.1257/jep.29.1.89. 
Ganuza, E. and Baiocchi, G. (2012). 'The Power of Ambiguity: How Participatory Budgeting Travels the Globe'. Journal of Public Deliberation 8 (2). URL: http://www . publicdeliberation. net/jpd/vol8/iss2/art8.

Gauchat, G. (2011). 'The cultural authority of science: Public trust and acceptance of organized science'. Public Understanding of Science 20 (6), pp. 751-770. DOI: $10.1177 / 0963662510365246$.

Holmes, D. R. (2009). 'Economy of words'. Cultural Anthropology 24 (3), pp. 381-419.

- (2013). Economy of words: communicative imperatives in central banks. Chicago, U.S.A.: University of Chicago Press.

Irwin, A. (1995). Citizen Science: a Study of People, Expertise and Sustainable Development. Routledge.

- (2001). 'Constructing the scientific citizen: science and democracy in the biosciences'. Public Understanding of Science 10 (1), pp. 1-18. DOI: $10.1088 / 0963-6625 / 10 / 1 / 301$.

Jacob, R., Christandl, F. and Fetchenhauer, D. (2011). 'Economic experts or laypeople? How teachers and journalists judge trade and immigration policies'. Journal of Economic Psychology 32 (5), pp. 662-671. DOI: $10.1016 / \mathrm{j} \cdot$ joep. 2011.06.006.

Jappelli, T. (2010). 'Economic Literacy: An International Comparison'. The Economic Journal 120 (548), F429-F451.

Jasanoff, S. (2003a). 'Breaking the Waves in Science Studies Comment on H.M. Collins and Robert Evans, "The Third Wave of Science Studies". Social Studies of Science 33 (3), pp. 389-400. DOI: 10.1177/03063127030333004.

- (2003b). '(No?) Accounting for expertise'. Science and Public Policy 30 (3), pp. 157-162. DOI: $10.3152 / 147154303781780542$.

- (2011). Designs on nature: Science and democracy in Europe and the United States. Princeton, U.S.A.: Princeton University Press.

Johnston, C. D. and Ballard, A. O. (n.a.). 'Economists and Public Opinion: Expert Consensus and Economic Policy Judgment'. Working paper. URL: http://www . tessexperiments . org/data/johnstonbr4.pdf.

Kemp, S. (2008). 'Lay attitudes to trade with low-wage countries'. Judgment and Decision Making 3 (4), pp. 335-343.

Kinchy, A. (2017). ‘Citizen Science and Democracy: Participatory Water Monitoring in the Marcellus Shale Fracking Boom'. Science as Culture 26 (1), pp. 88-110. DOI: $10.1080 / 09505431.2016 .1223113$.

Latour, B. (2005). 'From Realpolitik to Dingpolitik: Or how to make things public'. Exhibition at Center for Art and Media Karlsruhe, 20 March - 03 October 2005. In: Making things public: atmospheres of democracy. Exhibition at Center for Art and Media Karlsruhe, 20 March - 03 October 2005. Ed. by B. Latour and P. Weibel. Cambridge, MA, U.S.A.: MIT Press, pp. 14-41.

Latour, B. and Weibel, P., eds. (2005). Making things public: atmospheres of democracy. Exhibition at Center for Art and Media Karlsruhe, 20 March - 03 October 2005. Cambridge, MA, U.S.A.: MIT Press.

Lusardi, A. (2015). 'Financial literacy: Do people know the ABCs of finance?' Public Understanding of Science 243, pp. 260-271. DOI: 10.1177/0963662514564516.

Lusardi, A. and Mitchell, O. S. (2008). Planning and Financial Literacy: How Do Women Fare? Cambridge, MA: National Bureau of Economic Research. DOI: 10.3386/w13750. URL: http://www . nber.org/papers/w13750. pdf. 
Lusardi, A. and Mitchell, O. S. (2009). How Ordinary Consumers Make Complex Economic Decisions: Financial Literacy and Retirement Readiness. Cambridge, MA, U.S.A.: National Bureau of Economic Research. DOI: 10.3386/w15350.

- (2011). 'Financial literacy around the world: an overview'. Journal of Pension Economics and Finance 10 (4), pp. 497-508. DOI: 10.1017/S1474747211000448.

- (2013). The Economic Importance of Financial Literacy: Theory and Evidence. Cambridge, MA, U.S.A.: National Bureau of Economic Research. DOI: $10.3386 / \mathrm{w} 18952$.

MacDowell, M. A. (1986). 'Increasing the Public's Understanding of Economics: What Can We Expect From the Schools?' The American Economic Review 76 (2), pp. 145-148.

Mackenzie, D. (2006). 'Is economics performative? Option theory and the construction of derivatives markets'. Journal of the History of Economic Thought 28 (1), pp. 29-55. DOI: 10.1080/10427710500509722.

- (2008). An engine, not a camera: How financial models shape markets. Cambridge, MA, U.S.A.: MIT Press.

Malleson, T. (2013). 'Economic Democracy: The Left's Big Idea for the Twenty-First Century?' New Political Science 35 (1), pp. 84-108. DOI: $10.1080 / 07393148.2012 .754670$.

- (2014). After occupy: Economic democracy for the 21st century. Oxford, U.K.: Oxford University Press.

Markow, D. and Bagnashchi, K. (2005). What American teens and adults know about economics. Harris Interactive market research project for National Council on Economic Education.

Marquetti, A., Silva, C. E. Schonerwald da and Campbell, A. (2012). 'Participatory Economic Democracy in Action: Participatory Budgeting in Porto Alegre, 1989-2004'. Review of Radical Political Economics 44 (1), pp. 62-81. DOI: $10.1177 / 0486613411418055$.

Marres, N. (2005). 'Issues spark a public into being: A key but often forgotten point of the Lippmann-Dewey debate'. Exhibition at Center for Art and Media Karlsruhe, 20 March - 03 October 2005. In: Making things public: atmospheres of democracy. Exhibition at Center for Art and Media Karlsruhe, 20 March - 03 October 2005. Ed. by B. Latour and P. Weibel. Cambridge, MA, U.S.A.: MIT Press, pp. 208-217.

McNulty, S. L. (2015). 'Barriers to Participation: Exploring Gender in Peru's Participatory Budget Process'. The Journal of Development Studies 51 (11), pp. 1429-1443. DOI: 10.1080/00220388.2015.1010155.

Medvecky, F. and Macknight, V. (2015). 'Who Can Solve Our Biggest Challenges? Perceptions of the Relative Importance of Science and Economics'. SSRN Electronic Journal. DOI: 10.2139/ssrn. 2650925.

Miller, S. (2001). 'Public understanding of science at the crossroads'. Public Understanding of Science 10 (1), pp. 115-120. DOI: 10 .1088/0963-6625/10/1/308.

Navarro, Z. (2004). 'Participatory Budgeting in Porto Alegre, Brazil'. In: Leadership and Innovation in Subnational Government. Ed. by T. Campbell and H. Fuhr. Washington DC, U.S.A.: The World Bank Institute, pp. 177-212.

Nelson, J. A. and Sheffrin, S. M. (1991). 'Economic Literacy or Economic Ideology?' Journal of Economic Perspectives 5 (3), pp. 157-165. DOI: 10.1257/jep. 5.3.157. 
Nitzsche, P., Pistoia, A. and Elsäßer, M. (2012). ‘Development Of An Evaluation Tool For Participative E-Government Services: A Case Study Of Electronic Participatory Budgeting Projects In Germany'. Revista Administratie si Management Public (RAMP) 18, pp. 6-25.

URL: https://ideas.repec.org/a/rom/rampas/v2012y2012i18p6-25.html.

O'Brien, T. L. (2013). 'Scientific authority in policy contexts: Public attitudes about environmental scientists, medical researchers, and economists'. Public Understanding of Science 22 (7), pp. 799-816. DOI: 10.1177/0963662511435054.

Owen, R., Macnaghten, P. and Stilgoe, J. (2012). 'Responsible research and innovation: From science in society to science for society, with society'. Science and Public Policy 39, pp. 751-760.

Poon, M. and Olen, H. (2015). 'Does literacy improve finance?' Public Understanding of Science 24 (3), pp. 272-284. DOI: 10.1177/0963662515571209.

Priest, S. (2013). 'Critical Science Literacy: what Citizens and Journalists Need to Know to Make Sense of Science'. Bulletin of Science, Technology and Society 33 (5-6), pp. 138-145. DOI: 10.1177/0270467614529707.

Royal Society (1985). The Public Understanding of Science. London, U.K.: Royal Society. URL: https://royalsociety.org/ /media/Royal_Society_Content/p olicy/publications/1985/10700.pdf.

Salemi, M. K. (2005). 'Teaching Economic Literacy: Why, What and How'. International Review of Economics Education 4 (2), pp. 46-57. DOI: $10.1016 / \mathrm{S} 1477-3880$ (15) 30132-8.

Sapienza, P. and Zingales, L. (2013). 'Economic Experts vs. Average Americans'. SSRN Electronic Journal. DOI: 10.2139/ssrn. 2221527.

Souza, C. (2001). 'Participatory budgeting in Brazilian cities: limits and possibilities in building democratic institutions'. Environment and Urbanization 13 (1), pp. 159-184. DOI: 10.1177/095624780101300112.

Stigler, G. J. (1970). 'The Case, if Any, for Economic Literacy'. The Journal of Economic Education 1 (2), pp. 77-85. DOI: 10.1080/00220485.1970.10845301.

Stirling, A. (2008). "'Opening Up" and "Closing Down": Power, Participation, and Pluralism in the Social Appraisal of Technology'. Science, Technology, E Human Values 33 (2), pp. 262-294. DOI: 10.1177/0162243907311265.

Sturgis, P. and Allum, N. (2004). 'Science in Society: Re-Evaluating the Deficit Model of Public Attitudes'. Public Understanding of Science 13 (1), pp. 55-74. DOI: $10.1177 / 0963662504042690$.

Talpin, J. (2012). Schools of democracy: how ordinary citizens (sometimes) become competent in participatory budgeting institutions. Colchester, U.K.: ECPR Press.

Thomas, G. and Durant, J. (1987). 'Why should we promote the public understanding of science'. Scientific literacy papers 1, pp. 1-14.

Vaughan, E. T. (2014). Reconstructing Communities: Participatory Recovery Planning In Post-Disaster Japan. U.S.A.: Cornell University.

Walstad, W. B. (1997). 'The Effect of Economic Knowledge on Public Opinion of Economic Issues'. The Journal of Economic Education 28 (3), pp. 195-205. DOI: $10.1080 / 00220489709596744$.

Walstad, W. B. and Rebeck, K. (2002). 'Assessing the economic knowledge and economic opinions of adults'. The Quarterly Review of Economics and Finance 42 (5), pp. 921-935. DOI: 10.1016/S1062-9769(01)00120-X. 
Wampler, B. (2000). A guide to Participatory Budgeting. International Budget Partnership. URL: http://www . internationalbudget .org/wp-content/upload s/A-Guide-to-Participatory-Budgeting.pdf.

Williamson, M. R. and Wearing, A. J. (1996). 'Lay people's cognitive models of the economy'. Journal of Economic Psychology 17 (1), pp. 3-38. DOI: 10.1016/0167-4870(95)00033-X.

Willis, L. (2008). 'Against Financial-Literacy Education'. Iowa Law Review, pp. 197-285.

Wobker, I., Kenning, P., Lehmann-Waffenschmidt, M. and Gigerenzer, G. (2014). 'What do consumers know about the economy?: A test of minimal economic knowledge in Germany'. Journal für Verbraucherschutz und Lebensmittelsicherheit 9 (3), pp. 231-242. DOI: 10.1007/s00003-014-0869-9.

Wynne, B. (1998). 'May the Sheep Safely Graze? A Reflexive View of the Expert-Lay Knowledge Divide'. In: Risk, Environment and Modernity: Towards a New Ecology. Chapter 2. Ed. by S. Lash, B. Szerszynski and B. Wynne. London, U.K.: SAGE Publications Ltd, pp. 44-83. DOI: http://dx.doi.org/10.4135/9781446221983.n3.

Authors

\section{How to cite} Attribution - NonCommercial - NoDerivativeWorks 4.0 License. ISSN 1824-2049. Published by SISSA Medialab. jcom.sissa.it learning from science communication and science studies.'. JCOM 16 (02), A01. 